\title{
TAREKAT 'ALAWIYYAH DI KALIMANTAN SELATAN: Sebuah Telaah Unsur Neo-Sufisme dalam Tarekat
}

\begin{abstract}
Abdul Hakim*
ABSTRACT

As a known tarekat, the tarekat 'Alawiyah basically insists on planting experience of shariah and noble character. Tarekat 'Alawiyah in South Kalimantan taught by teacher Bachiet also emphasized the moral aspect of his disciples. Moral formation was through the Majelis taklim assemblies. Among its activities are sympathize widows, orphans and habaib. The establishment of moral and social activity is an essential element in the neo-Sufism. In addition, remembrance and carried muraqabah also an element of neo-Sufism. But the use of the drikir of isim mufrad and dhamir "Hua" is the influence of philosophical sufism is mostly found in South Kalimantan. Practice of the tarekat by taking account of social activity are part of the neo-Sufism that need to be developed, so that they practice this Sufism (the tarekat) is also directly involved with issues facing today's society.
\end{abstract}

Kata kunci: tarekat 'Alawiyyah, neo-sufisme, zikir

\section{Pendahuluan}

Bermunculannya tarekat-tarekat di Indonesia boleh dikatakan merupakan salah satu gejala keagamaan Islam yang menonjol. Padahal tidak semua negeri Islam mempunyai gejala-gejala serupa. Republik Turki dan Kerajaan Saudi Arabia merupakan negeri-negeri yang melarang adanya tarekat meskipun dengan alasan yang berbeda. Turki melarangnya karena tarekat dipandang sebagai gejala kebodohan dan tidak sesuai dengan semangat pembaharuan, ${ }^{1}$ sedangkan Saudi Arabia melarangnya karena dianggap menyimpang dari ajaran yang benar. Selain kedua negara itu boleh dikatakan mengizinkan atau

*Dosen tetap Fakultas Ushuluddin IAIN Antasari Banjarmasin.

1Pelarangan tarekat di Turki oleh Mustafa Kemal Ataturk sejak tahun 1925 dan setelah tahun 1980 kelompok tarekat mulai bermunculan kembali, salah satu tarekat yang punya pengaruh terhadap politik bangsa Turki adalah tarekat Naqsyabandiyah. (Lihat: Martin van Bruinessen dalam pengantar buku "Politik. Tarekat Qadiriyah wa Naqsyabandiyah Jombang" tulisan Mahmud Sujuthi, h. xiii) 
membiarkan adanya tarekat-tarekat. Dapat disebutkan bahwa negeri kita termasuk yang terakhir ini.

Martin Van Bruinessen mengemukakan bahwa di Indonesia pada paruh kedua dasawarsa 1980-an minat masyarakat Indonesia terhadap tasawuf dan keikutsertaan dalam aktivitas tarekat mulai meningkat saat itu. Bahkan dianulir pengikut dari tarekat ini bukan hanya dari kalangan NU, melainkan juga segelintir orang Muhammadiyah mulai tertarik dan ikut serta dalam sebuah tarekat. $^{2}$

Perkembangan tarekat di Indonesia terkait dengan teori yang umum diterima, yaitu bahwa Islam datang ke kawasan ini melalui gerakan kesufian dalam tarekat-tarekat. Jika dikaitkan dengan fakta sejarah bahwa Islam berkembang pesat sejak jatuhnya kerajaan Hindu Majapahit pada sekitar awal abad ke-15, maka peranan gerakan kesufian dalam mengembangkan Islam di negeri ini mencocoki gejala umum yang terjadi dalam dunia Islam. Demikian pula jika diingat bahwa tokoh-tokoh keagamaan masa lalu banyak disebut wali, maka adanya peranan yang besar dari kaum sufi itu juga merupakan keterangan yang dapat diterima tentang fakta tersebut. Jadi terlihat jelas bahwa adanya corak kesufian yang kuat, yang melembaga dalam tarekat-tarekat, adalah bagian dari fakta sejarah masuknya Islam yang punya karakteristik sufistik dan berkembang hingga sekarang.

Di Kalimantan Selatan, yang mayoritas penduduknya beragama Islam juga telah tumbuh dan berkembang pelbagai macam aliran tarekat. Di antara aliran tarekat yang berkembang di daerah ini adalah tarekat 'Alawiyyah yang tentunya punya karakteristik tersendiri dengan berafiliasinya berbagai tarekat ke dalamnya dan berbagai pembaharuan terhadap ajarannya. Sebagaimana dikemukakan oleh Fazlur Rahman, bahwa neo-sufisme juga masuk ke dalam gerakan tarekat. Fazlur Rahman mengemukakan tarekat Sanusiyah di Afrika Utara sebagai gerakan neo-sufisme yang terdapat di dalamnya berbagai macam pembaharuan yang mengarah kepada positivisme psikologis untuk keuntungan sosial daripada semangat materialistik (keduniawian). Neo-sufisme tersebut tentunya juga tidak menutup kemungkinan dapat ditemukan dalam tarekat 'Alawiyyah di Kalimantan Selatan. Karenanya dalam tulisan ini, penulis akan melakukan kajian mengenai unsur-unsur neo-sufisme dalam tarekat 'Alawiyyah tersebut.

\section{Historisitas Tarekat 'Alawiyyah}

${ }^{2}$ Bruinessen, "Pengantar" ..., h. xiv 
Tarekat 'Alawiyyah adalah salah satu tarekat muktabarah dari 41 tarekat yang ada di dunia Islam. Tarekat ini berasal dari Hadhramaut, Yaman Selatan, dan tersebar di Indonesia.

Pengelompokan tarekat kepada tarekat muktabarah dan tidak muktabarah muncul belakangan dengan maksud menjaga kemurnian ajaran Islam. Menyikapi pengelompokan tersebut tidak mustahil muncul perbedaan pendapat dalam menentukan apakah suatu tarekat dapat dikatakan muktabarah atau tidak muktabarah. Untuk itu diperlukan adanya alat ukur yang standar dan disepakati. Pertama, ajaran suatu tarekat tidak bertentangan dengan esensi ajaran Islam yang terkandung dalam Alquran dan hadis, baik dari asfek akidah ataupun syariah. Kedua, silsilahnya memiliki persambungan dari segi sanad. Tarekat 'Alawiyyah jelas memenuhi kedua kriteria dimaksud. Dengan demikian, tarekat ini dapat dikatakan sebagai tarekat yang muktabarah.

Tarekat 'Alawiyyah didirikan oleh Imam 'Alawî bin 'Ubaidillâh bin 'Isâ bin Ahmad al-Muhâjir, seorang tokoh sufi terkemuka asal Hadhramaut, pada abad ke-17 M. Sebagai cikal bakalnya, sudah dimulai pada masa Muhammad bin 'Alî, yang akrab dengan panggilan al-Faqîh al-Muqaddam, seorang ahli agama yang terpandang pada abad ke-6 dan ke-7 H. Beliau adalah seorang ulama besar yang memiliki pengetahuan di bidang fikih dan tasawuf serta pengalaman spiritual yang tinggi hingga ke maqâm al-quthbiyyah (puncak maqam kaum sufi) dan birqah sûfiyyah (legalitas kesufian).

Tarekat 'Alawiyyah, secara umum, adalah tarekat yang dikaitkan dengan kaum 'Alawiyyin atau yang lebih dikenal sebagai sadah atau kaum sayyid, keturunan Nabi Muhammad saw., yang merupakan lapisan paling atas dalam strata masyarakat Hadhrami. Karena itu, pada masa-masa awal tarekat ini didirikan, pengikut tarekat 'Alawiyyah kebanyakan dari kaum sayyid (kaum Hadhrami) atau kaum Ba 'Alawi, dan setelah itu diikuti oleh berbagai lapisan masyarakat muslim lain non Hadhrami.

Tarekat 'Alawiyyah memiliki kekhasan tersendiri dalam pengamalan wirid dan zikir bagi para pengikutnya, yakni tidak adanya keharusan bagi para murid untuk terlebih dahulu dibai'at, ditalqin, atau mendapatkan khirqah (ijazah), jika ingin mengamalkan tarekat ini. Dengan kata lain, tarekat 'Alawiyyah boleh diikuti atau dipraktikkan oleh siapa saja tanpa harus berguru sekalipun kepada mursyidnya. Demikian pula dalam pengamalan ajaran zikir dan wiridnya relatif cukup ringan, karena tarekat ini hanya menekankan segi-segi amaliah dan akhlak (tasawuf amali dan akhlaki), sementara dalam tarekat lain biasanya cenderung melibatkan latihan-latihan (riyadah-riyadah) secara fisik dan 
kezuhudan yang ketat. ${ }^{3}$ Oleh karena itu, Umar Ibrahim lebih cenderung untuk tidak mengatakan bahwa tarekat 'Alawiyyah sebagai tarekat (dalam arti organisasi), akan tetapi hanya sebuah suluk untuk mendekatkan diri kepada Allah swt. bagi orang yang mengamalkannya. ${ }^{4}$

Dalam perjalanan sejarah selanjutnya tarekat 'Alawiyyah dikembangkan oleh Sayyid 'Abdullâh al- $\underline{H}$ addâd sebagai generasi penerus. Dari nama tokoh inilah, tarekat 'Alawiyyah juga dikenal dengan nama Tarekat $\underline{\text { Haddâdiyyah }}{ }^{5}$ (tarekat 'Alawiyyah yang diperbaharui). Dengan semakin bertambah banyaknya pengikut tarekat ini dan tersebar di beberapa negara, tarekat ini dalam perkembangannya melahirkan dua cabang tarekat, yakni tarekat 'Aidarûsiyyah dan tarekat 'Aththâsiyyah. ${ }^{6}$

Dengan demikian dalam perkembangan selanjutnya Tarekat 'Alawiyyah tidak dapat lagi dipilah dan dipisahkan dari Tarekat Haddâdiyyah. Bahkan belakangan sebutan Tarekat Haddâdiyyah lebih populer, karena hal ini dinisbahkan dengan ratib Haddâdnya dan pembaharuan di dalam ajaran Tarekatnya.

\section{Sayyid 'Abdullâh al- $\underline{H a d d a ̂ d ~ P e m b a h a r u ~ T a r e k a t ~ ' A l a w i y y a h ~}$}

Nama lengkap Sayyid 'Abdullâh al-Ḧaddâd adalah al-Imam al-Sayyid

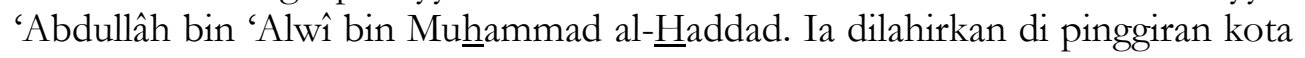
Tarim, sebuah kota yang termasuk wilayah Hadhramaut (Yaman Selatan), pada malam Senin, 5 Safar 1044 H./1636 M., dan wafat pada malam Selasa tanggal 7 Zulqa'dah 1132 H./1724 M. dalam usia delapan puluh delapan tahun. Ia

${ }^{3}$ Nanang Syaikhu, Tarekat Alawiyyah, dalam Sufi Menuju Jalan Ilahi, Edisi 16, September 2001, h. 46-47.

${ }^{4}$ Umar Ibrahim, Tarekat Alawiyyah Bukan Organisasi Tarekat, dalam Sufi Menuju Jalan Ilahi, Edisi 16, September 2001, h. 52-54.

${ }^{5}$ Disebut Tarekat Haddâdiyyah karena tarekat ini lebih memasyarakat dan sangat kental dengan ajaran-ajaran Syaikh al-Haddâd, terutama yang kita kenal dengan ratib Haddâd. Sebagai salah satu ajaran al-Haddâd yang dikembangkan dalam tarekatnya adalah lebih fleksibel dalam pengamalannya dan terbuka bagi semua kalangan, bahkan menurut Umar Ibrahim bisa saja diamalkan tanpa seorang mursyid. Lihat : Umar Ibrahim, Tharíqah 'Alawiyyah: Napak Tilas dan Studi Kritis atas Sosok dan Pemikiran Allamah Sayyid 'Abdullâh Al-Haddâd Tokoh Sufi Abad ke-17, Selanjutnya disebut Tharíqah 'Alawiyyah, (Bandung: Mizan, 2001), h. 10.

'Azyumardi Azra, 'Pengantar", dalam Umar Ibrahim, Tharíqah 'Alawiyyah: Napak Tilas dan Studi Kritis atas Sosok dan Pemikiran Allamah Sayyid 'Abdullâh Al-Haddâd Tokob Sufi Abad ke17, (Bandung: Mizan, 2001), h. xix. 
memiliki garis keturunan sampai kepada Sayyidina 'Alî bin Abî Thâlib dan Fâthimah binti Muhammad saw., ibunya bernama Syarifah Salma, seorang ahli ma'rifah dan wilayah. ${ }^{7}$

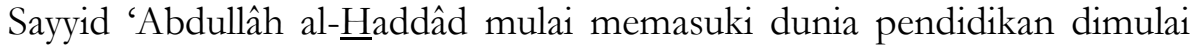
dengan belajar kepada orang tuanya, kemudian kepada beberapa orang guru di daerah kelahirannya untuk mempelajari Alquran dan beberapa ilmu dasar.

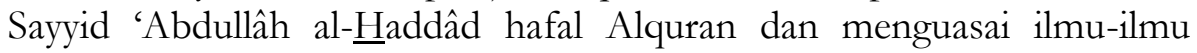
dasar. Dengan penuh kesungguhan ia pun melanjutkan pelajaran kepada ilmuilmu keislaman yang lebih tinggi.

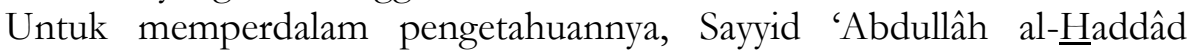
melakukan pengembaraan ke berbagai kota di luar kota Hadhramaut hingga sampai ke Makkah dan Madinah. Selama pengembaraan menuntut ilmu, ia belajar kepada sejumlah guru. Guru-gurunya antara lain : 1) Sayyid 'Aqîl bin 'Abd al-Rahman bin 'Aqîl al-Saqqâf, seorang tokoh sufi mazhab Malamatiyah, dan daripadanya ia mendapatkan birqah (ijazah) kesufian; 2) Sayyid 'Umar bin 'Abd al-Rahmân bin Syihâb al-Dîn; 3) Sayyid 'Umar bin 'Abd al-Raḥmân al'Athtâs, seorang tokoh dalam ilmu tarekat, dan 4) Sayyid Abû Bakar bin 'Abd al-Rahmân bin Syihâb al-Dîn. ${ }^{8}$

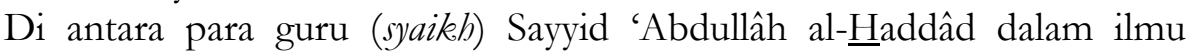
tarekat adalah Syaikh 'Alî bin 'Abdullâh al-'Aidarûs, Syaikh Ahmad bin Husîn bin 'Abdullâh bin Syaikh al-'Aidarûs, al-'Ârif billâh Syaikh Zain bin al-Imâm Husîn Bâ Fadhl, Sayyid al-

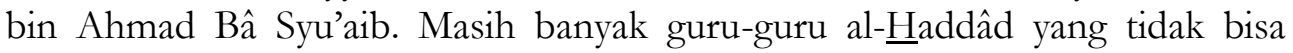
dikemukakan, yang menurut pengakuannya sendiri berjumlah lebih dari seratus orang guru. Sayyid 'Abdullâh al- $\underline{H}$ addâd tidak hanya memiliki ilmu, tetapi dalam kehidupannya ia mempraktikkan ilmu kesufian, memiliki spiritualitas yang sangat tinggi dan senang beribadah. Ada pula yang mengatakan bahwa beliau setiap hari berkeliling kota Tarim untuk beribadah dalam masjid yang dijumpainya.

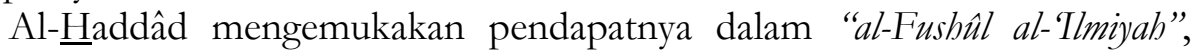
bahwa inti dari tasawuf adalah memurnikan tauhid dan beberapa syirik, kemudian dilanjutkan dengan menumbuhkan akhlak yang terpuji seperti zuhud, ikhlas, dan bersedih hati terhadap kaum muslimin. Hal ini dibarengi dengan menghilangkan segala bentuk sifat buruk seperti cinta dunia, riya dan angkuh. h. 265 .

${ }^{7}$ M. Laily Mansur, Ajaran dan Teladan Para Sufi, (Jakarta: RajaGrafindo Persada, 1999), 'Ibrahim, Tharíqah' Alawiyyah..., h. 265-266. 
Kemudian melakukan amal saleh yang nyata dan menjauhi perbuatan buruk, mencari nafkah dengan baik melalui jalan wara' dan qana'ah. Tasawuf bagi al- Haddâd adalah ibadah, akhlak dan zikir, suatu jalan membina dan memperkuat kemandirian menuju Tuhan. ${ }^{9}$

Menurut pandangan al- $\underline{H} a d d a ̂ d$, tarekat 'Alawiyyah merupakan tharíqah ashbâb al-yamîn, yakni tarekatnya orang-orang yang menghabiskan waktunya untuk ingat dan taat kepada Allah dan selalu menjaganya dengan melakukan hal-hal yang bersifat ukhrawi. Tampaknya, al'Alawiyyah menjadi dua macam, yakni tharíqah al-khâshshah atau tarekat kaum muqarrabîn (elite kaum sufi), dan tharígah 'âmmah (tharîah ashhâb al-yamîn). Beliau sangat menekankan pada tarekat yang bersifat umum (âmmah), bahkan dikatakannya bahwa masyarakat pada masanya tidak pantas mengikuti tarekat khâshshah. Kunci memasuki tarekat khâshshah adalah : (1) mengosongkan diri, baik lahir maupun batin, dari selain Allah; (2) membersihkan diri dari segala macam perangai tak terpuji hingga yang terkecil, dan (3) menghiasi diri dengan perangai yang terpuji hingga yang terkecil. ${ }^{10}$

Berbeda halnya dengan Tarekat Naqsyabandiyah, sebagaimana dijelaskan M. Amin al-Kurdi, ${ }^{11}$ sebelum penyucian diri (tąkiyah) seorang sâlik lebih dahulu dikonsentrasikan pada penjernihan diri (tashfiyab) dan Tuhan secara sungguh-sungguh. Dengan begitu diharapkan penyucian diri akan tercapai melalui karunia kepekaan jiwa dan rasa dari Allah dalam waktu sesingkat mungkin yang tidak akan dicapai dengan cara-cara olah batin (mental training) dalam satu tahun. Hal ini karena mendahulukan kepekaan jiwa dan rasa (jad₹̧bab) atas perjalanan spiritual (sulukk). Di dalam perbedaannya dengan Tarekat Naqsyabandiyah tersebut, Tarekat 'Alawiyyah secara implisit juga menawarkan tashfiyah, yakni dengan mengkonsentrasikan diri secara penuh kepada Tuhan dan dibarengi dengan tąkiyah, yakni dengan membersihkan hati dari berbagai kotoran, baik syirik khafi, riya dan perilaku yang bisa mengotori hati.

Al- $\underline{\text { H}}$ addâd lebih lanjut menerangkan bahwa tarekat Bâ 'Alawî' ialah tarekatnya para sayyid dari keturunan 'Alî (al-'Alawiyyîn) dari jalur Imam Husain

'Ibrahim, Tharíqab 'Alawiyyah..., h. 267-269.

${ }^{10} \mathrm{Ibrahim}$, Tharíqah 'Alawiyyah..., h. 105-107.

${ }^{11}$ Muhammad Amin al-Kurdi, Tanwîr al-Qulûb, Bab III, diterjemahkan oleh Ilyas Siraj dengan judul Berjalan Menuju Tuban: Kode Etik Tarekat Naqsyabandiyah, (Yogyakarta: Harapan Utama, 2001), h. 5.

${ }^{12}$ Istilah Bâ 'Alawî adalah singkatan dari Bani 'Alawî, keturunan dari Imam 'Ubaidullâh bin Ahmad bin 'Îsâ dari Hadhramaut. Lihat: Ibrahim, Tharîqah' Alawiyyah..., h. 39-40. 
yang ada di Hadhramaut. Tarekat mereka berdasarkan Alquran, al-Sunnah, riwayat-riwayat yang benar, dan ajaran para salaf yang mulia. Para salaf Bâ 'Alawî mempunyai keunggulan dibandingkan dengan lainnya karena mereka mendapatkan ajaran sesuai dengan urutan nasab mereka, yakni dari anak, ke ayah, kakek, dan begitu seterusnya kepada Nabi Muhammad saw.

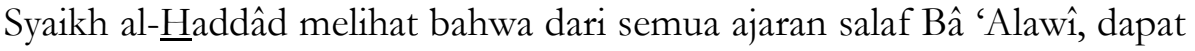
disimpulkan secara umum bahwa ajaran tarekat mereka ialah menekankan adanya hubungan dengan seorang syaikh (guru pembimbing dalam ibadah), perhatian secara saksama dengan ajarannya, dan membina batin/sirr (dengan ibadah). Selain itu, menurut Syaikh al- $\underline{H}$ addâd, tarekat ini juga menekankan pentingnya amal, dan untuk itu, dibutuhkan suatu tarekat yang ajarannya mudah dilakukan dan dipahami masyarakat awam pada umumnya.

Secara terperinci, Syaikh al-Haddâd mengatakan bahwa hidup ini adalah safar (sebuah perjalanan menuju Tuhan). Safar, menurut ahli tasawuf, adalah siyâhah rübâniyyah (perjalanan rekreatif yang bersifat rohani). Safar menurut mereka adalah suatu cara untuk melakukan perlawanan terhadap hawa nafsu dan sebagai media pendidikan moral. Sebagaimana diungkapkan oleh Syaikh Muhyî al-Dîn Ibn 'Arabî bahwa safar adalah ber-tawajjub-nya hati kepada alHaqq (Yang Maha Benar) dengan zikir.

Dalam menempuh safar tersebut, maka seorang sâlik (orang yang melakukan sulukk) harus senantiasa berusaha untuk:

1. Menyelamatkan diri (salamah al-shadr) dari penyakit-penyakit hati, termasuk juga memperhatikan segala hal yang dapat mengotori hati. Sa'id Hawwa ${ }^{13}$ mengatakan bahwa penyakit hati (jiwa) itu ada dua macam, yakni: i). Bentuk penyakit yang meniadakan berbagai maqam hati. Misalnya riya' dan kemusyrikan menafikan tauhid dan 'ubûdiyyah, sedangkan cinta kepemimpinan, cinta kedudukan dan cinta dunia meniadakan zuhud. ii). Bentuk penyakit yang menafikan takhalluq dengan nama-nama Allah dan penauladanan kepada Rasulullah saw. Misalnya marah bukan pada tempatnya meniadakan kesantunan.

\footnotetext{
${ }^{13}$ Sa'id Hawwa, Al-Mustakblash fì tazkiyah al-Anfus, diterjemahkan oleh Aunur Rafiq Shaleh Tamhid dengan judul Mensucikan Jiwa /Konsep Tazkiyatun-nafs Terpadu: Intisari Ibya' 'Ulûmuddin al-Ghazâl, (Jakarta: Robbani Press, 2000), h. 180. Mengenai metode tą̧kiyah al-nafs juga dikemukakan oleh Mir Valiuddin dengan metode yang lebih praktis, mulai dari berwudhu, shalat (fardhu dan sunnah), zikir, tasbih dan istighfar. Lihat: Mir Valiuddin, Contemplative Disciplines in Sufism, diterjemahkan oleh M.S. Nasrlloh dengan judul Zikir dan Kontemplasi dalam Tasawuf, (Bandung: Pustaka Hidayah, 1997), h. 106-120.
} 
2. Berbaik sangka terhadap Allah ( $\underline{b u s n}$ al-z̧hann billâh) dan terhadap makhluk-Nya.

3. Zuhud terhadap dunia dan cinta akhirat.

4. Memperhatikan hak-hak makhluk Allah.

5. Memuliakan ilmu, ulama, para wali, orang muslim dan mukmin.

Kelima poin di atas merupakan ajaran dasar tarekat 'Alawiyyah, yang pada dasarnya lebih menekankan pada riyâdhah al-qulûb tanpa mengesampingkan riyâdhah al-abdân dengan menjalankan syariat. Oleh karena itulah tarekat 'Alawiyyah berada pada posisi antara tarekat Ghazâliyyah dan tarekat Syâdziliyyah. ${ }^{14}$

Selanjutnya, al-Haddâd mengatakan bahwa untuk sampai kepada derajat sufi sejati (shufî kamîl) dibutuhkan tahapan-tahapan dalam pembenahan diri, dan yang terpenting dari tahapan itu ialah ishlâh al-sarîrah (pebenahan atau pembersihan batin) dari hal-hal yang menghalangi seseorang sampai ke Tuhan (al-wushûl) dan sikap murâqabah.

Secara lebih terperinci al-Haddâd mengemukakan beberapa kiat yang harus dilakukan agar sampai pada derajat shufi kamîl tersebut, yaitu :

1. Membersihkan amal, perkataan, niat dan moral dari penyakit riya' (pamer).

2. Menyucikan diri dari segala sesuatu yang menyebabkan murka Sang Pencipta (Allah).

3. Mendatangi Allah dengan lahir dan batinnya, dan begitu juga dalam melakukan segala ketaatan kepada-Nya, serta hanya ingat kepada-Nya.

4. Memutuskan hubungan dengan apa saja yang dapat melupakannya.

5. Semua itu dia lakukan berdasarkan pada ilmu, Alquran, Sunnah, dan ajaran para salaf yang saleh. ${ }^{15}$

Menurut M. Laily Mansur dalam bukunya "Tasawnf Islam", bahwa pada dasarnya setiap amalan tarekat dilaksanakan untuk berbagai keperluan, di antaranya :

1. Dengan mengamalkan tarekat berarti mengadakan latihan jiwa (riyâdhah) dan berjuang melawan hawa nafsu (mujâhadah), membersihkan diri dari sifat-sifat tercela dan diisi dengan sifat-sifat terpuji dengan melalui perbaikan budi pekerti dalam berbagai seginya.

\footnotetext{
${ }^{14}$ Ibrahim, Thariqah 'Alawiyyah..., h. 108-110.
}

${ }^{15}$ Ibrahim, Thariqab 'Alawiyyah..., h. 149-151. 
2. Selalu dapat mewujudkan rasa ingat kepada Allah Zat Yang Maha Besar dan Maha Kuasa atas segalanya dengan melakukan berbagai wirid dan zikir dibarengi tafakkur yang secara teratur diamalkan.

3. Dari sini timbul perasaan takut kepada Allah swt., sehingga timbul pula dalam diri seseorang itu suatu usaha untuk menghindarkan diri dari berbagai macam pengaruh duniawi yang dapat menyebabkan lupa kepada Allah swt.

4. Jika hal itu semua dapat dilaksanakan dengan penuh ikhlas dan ketaatan kepada Allah, maka tidak mustahil akan dapat dicapai suatu tingkat ma'rifat, sehingga dapat pula diketahui segala rahasia di balik tabir cahaya Allah dan Rasul-Nya secara terang benderang.

5. Akhirnya dapatlah diperoleh apa yang sebenarnya menjadi tujuan hidup ini. ${ }^{16}$

Jelaslah bahwa tarekat di sini, termasuk pula tarekat 'Alawiyyah, akan dapat mengerjakan syari'at Allah dan Rasul-Nya dengan melalui jalan atau sistem yang menghantarkan tercapainya tujuan hidup yang sebenarnya sesuai yang dikehendaki oleh syari'at itu sendiri.

\section{Perkembangan Tarekat 'Alawiyyah di Kalimantan Selatan}

Dari hasil penelitian ${ }^{17}$ yang pernah dilakukan, tarekat 'Alawiyyah di Kalimantan Selatan disebarkan oleh seorang Habîb, yaitu Habîb Zain Alaydrus yang berasal dari Surabaya, sekaligus sebagai peletak dasar tarekat ini. Sebagaimana yang dilakukan tokoh kaum 'Alawiyyîn di Hadhramaut, ajaran tarekat 'Alawiyyah di sini diambil dari berbagai macam tarekat yang berkembang di Indonesia, oleh Habîb Zain Alaydrus dipadukan amalan dan ajaran tarekat-tarekat tersebut, sehingga setelah mendapat restu dari para Habîb, terutama Habîb yang mengajarkan ajaran tarekat yang ada, seperti tarekat Sammâniyah, Naqsyabandiyah dan tarekat mu'tabarah lainnya, kemudian beliau menamakan tarekat ini dengan tarekat 'Alawiyyah.

Berdasarkan penelitian Martin van Bruinessen bahwa di Kalimantan Selatan tasawuf yang berkembang adalah tasawuf yang bercorak sufistik, seperti

\footnotetext{
${ }^{16}$ M. Laily Mansur, Tasawuf Islam: Mengenal Aliran dan Ajaran, (Banjarmasin: Lambung Mangkurat University Press, 1992), h.105-106.

${ }^{17}$ Mengenai perkembangan tarekat 'Alawiyyah di Kalimantan Selatan ini penulis mengambil referensi dari tulisan Asmaran As. "Aliran-aliran Tarekat di Kalimantan Selatan ('Alawiyyah, Sammaniyyah dan Tijaniyyah)" yang merujuk pada hasil penelitian Tim Fakultas Dakwah tahun 2001 dan tesis karya Siti Rahmah tahun 2004 yang berjudul "Tarekat 'Alawiyyah di Kabupaten Hulu Sungai Tengab”.
} 
ajaran nur Mubammad dan martabat tujuh, sehingga tarekat Naqsabandiyah yang ada di sini juga menyesuaikan diri dengan pola tersebut. ${ }^{18}$ Hal ini tentu berbeda dengan Tarekat 'Alawiyyah yang lebih moderat dan lebih mengarah kepada Tarekat yang sunni. Ini bukan berarti ajaran nur Muhammad dan martabat tujuh tidak diajarkan akan tetapi dalam Tarekat 'Alawiyyah lebih dikembangkan ke arah pembentukan akhlaqul karimah para muridnya dan pencapaian sebuah perjalanan spiritual.

Di Kalimantan Selatan tarekat ini antara lain berkembang di Kabupaten Hulu Sungai Tengah (HST), disebarkan oleh seorang ulama yang cukup terkenal di daerah tersebut, yaitu K.H. Bachiet A.M. melalaui majelis taklim yang dia pimpin, yang beralamat di jalan M. Ramli Barabai Darat. Pengajian di laksanakan pada setiap malam Selasa dan sore Kamis, diawali dengan pembacaan surah Yâsîn dan bacaan-bacaan amalan tarekat 'Alawiyyahitu sendiri yang dikenal dengan Wirid al-Haddâd dan wirid yang disusun oleh alHâbib Zain al-'Abidîn Ahmad Alaydrus (Surabaya).

Latar belakang pendidikan H.M. Bachiet adalah pendidikan formal hanya mencapai Sekolah Dasar kelas IV pada tahun 1976, selebihnya pendidikan non formal, yaitu dimulai dari didikan orang tuanya sebagai seorang ulama, kemudian mondok di pondok pesantren Ibnul Amin (Pemangkih) pada tahun 1977 kurang lebih tiga tahun. Kemudian pada tahun 1980 mondok di Pesantren Darussalam (Martapura) kurang lebih enam bulan. Setelah itu ia kembali lagi ke Barabai berguru kepada orang tuanya sendiri dan kepada para ulama yang berada di lingkungannya di antaranya adalah $\mathrm{H}$. Abdul Wahab dalam Ilmu Fiqh, dengan H. Hasan dan H. Saleh tentang Ilmu Nahwu. ${ }^{19}$

Sebagai seorang ulama dan guru tarekat 'Alawiyyah H.M. Bachiet telah menulis dua buah buku/kitab yang berhubungan dengan tasawuf/tarekat. Yang pertama berjudul Nûrul Mubibbîn fi Tarjamah Tharígat al-'Arifin min Sâdâtinâ alAwaliyyin, yang membahas tentang ajaran dan wirid yang harus dilakukan oleh seorang jemaah tarekat 'Alawiyyah. Yang kedua berjudul Ampunan Tuban (Bagi Orangyang Tobat dari Dosa dan Kesalahan).

Pada tahun 1993, H.M. Bachiet dikirim oleh orang tuanya ke Surabaya (Bangil) untuk berguru atau mengaji ilmu tarekat dengan Habib Zain al-'Abidin Ahmad Alaydrus, yang sebelumnya belum pernah dipelajarinya. Setelah

\footnotetext{
${ }^{18}$ Martin van Bruinessen, Tarekat Naqsyabandiyah di Indonesia, (Bandung: Mizan, 1995), h. 199-205.

${ }^{19}$ Asmaran As., "Aliran-aliran Tarekat di Kalimantan Selatan ('Alawiyyah, Sammaniyyah dan Tijaniyyah)" dalam Kandil, Edisi 4, tahun II, Pebruari 2004, h. 43-44.
} 
menerima pelajaran selama satu tahun, oleh guru dia dipandang telah mapan, dan selanjutnya diberi izin untuk memperkenalkan ajaran tarekat 'Alawiyyah dengan syarat jamaahnya tidak boleh kurang dari 40 orang.

Setelah pulang ke kampung halaman (Barabai) H.M. Bachiet berusaha mengumpulkan jamaah dari anggota keluarganya sendiri, para santri dan tokohtokoh masyarakat. Setealah mencapai 40 orang jamaah, maka mulailah dia memperkenalkan ajaran tarekat 'Alawiyyah. Pada tanggal 14 Juni 1994 (4 Muharram 1415 H.) didirikanlah sebuah majlis taklim Nûrul Muhibbîn yang bertempat di komplek pondok pesantren Nurul Muhibbin di jalan Muhammad Ramli Barabai Darat Kabupaten Hulu Sungai Tengah. ${ }^{20}$

Dalam praktik keseharian, khususnya saat pengajian, para jamaah harus berpakaian serba putih. Hal ini diharuskan oleh guru Bachiet atas petunjuk dari Habib Zain Alaydrus. Keharusan memakai pakaian serba putih, di samping memang dianjurkan oleh ajaran agama sebagaimana hadis yang sering dikemukakan sebagai dalilnya, juga bisa dipahami sebagai metode pendidikan rohani, dimana jamaah dikondisikan dalam situasi serba putih sebagai simbol bersih lahir dan batin dalam rangka mendekatkan diri kepada Allah swt.

Dalam usaha mendekatkan diri kepada Allah swt. diperlukan adanya bimbingan guru. Guru oleh jamaah 'Alawiyyah diyakini sebagai pemandu ibadah dan pembimbing spiritual dalam menempuh perjalanan tarekat. Melalui mata rantai spiritual (silsilah), guru akan menghantarkan muridnya menuju bimbingan Rasulullah yang menjadi pemandu utama mereka. Dengan demikian, bimbingan guru secara rohaniah adalah perwujudan hubungan rohani dengan Nabi saw.

Jabatan guru dalam tarekat ini harus dipegang oleh seseorang yang telah berhasil dalam melaksanakan keempat ajaran yang ditekankan dalam ilmu tasawuf, yaitu syariat, tarekat, hakikat dan makrifat. Yang paling utama, dia sudah menguasai ajaran pokok terakhir (makrifat). Dalam hal ini M. Amin Kurdi juga sependapat bahwa seorang guru (syaikh) seorang yang telah mencapai ma'rifah dan mempunyai ijazah dari gurunya untuk untuk menjalankan fungsi bimbingan, bukan atas dasar dorongan dirinya sendiri. Di samping itu seorang guru juga haruslah punya kapabilitas untuk membimbing murid-muridnya untuk mencapai Hadhirat Ilahi.

Di sisi lain, walaupun ilmu pengetahuan tentang syariat dan tarekat sudah memadai, namun jika hatinya tidak bersih, maka ia tidak boleh menjabat sebagai guru bagi siapa pun. Hal ini biasanya diakui oleh gurunya dalam bentuk

${ }^{20}$ Asmaran As., "Aliran-aliran Tarekat...", h. 44. 
pemberian ijazah sebagai pengakuan kebolehan dia untuk menjadi guru, menyampaikan ajaran tarekat yang dipelajarinya. Karena guru dalam hal ini akan bertindak sebagai pimpinan yang bukan hanya sekedar mengajar tetapi dia berperan sebagai pendidik dan pengawas seluruh kehidupan jasmaniah dan rohaniah para muridnya. Dikatakan bahwa guru, dalam tarekat biasa disebut syekh, mursyid atau muqaddin, sebagai orang yang bertugas mengawasi kehidupan jasmaniah dan rohaniah murid-muridnya. Oleh karenanya guru selalu mengawasi murid-muridnya dalam pergaulan sehari-hari agar tidak menyimpang dari ajaran-ajaran Islam dan jangan sampai terjerumus ke dalam lembah maksiat. Guru juga sebagai pemimpin kerohanian yang tertinggi dalam tarekat dan sebagai wasilah dalam perjalanan murid menuju Tuhan. ${ }^{21}$

Karena jabatannya yang begitu strategis, maka seorang guru harus memiliki tingkat makrifat yang tinggi hingga dia mampu mengenal kekuatan dan potensi setiap murid, yang pada gilirannya dapat memberikan tugas dan amalan yang sesuai dengan kapasitas murid dalam rangka mendekatkan diri kepada Tuhan. Karena posisinya yang sangat terhormat, maka tidak semua jamaah tarekat 'Alawiyyah dapat bertatap muka dengan guru (H.M. Bachiet).

Untuk dapat bergabung atau menjadi murid tarekat 'Alawiyyah, sebagaimana juga tarekat-tarekat lain, seorang calon murid haruslah terlebih dahulu mengadakan perjanjian dengan gurunya, yang disebut dengan bai'at atau ikrar setia. ${ }^{22}$ Dalam tarekat 'Alawiyyah di Kabupaten HST yang dipimpin H.M. Bachiet ini tidak semua jamaah bisa mendapatkannya. Bai'at hanya bagi orangorang tertentu saja yang mendapatkannya. Hal ini berarti tidak semua jamaah ditetapkan sebagai jamaah tarekat dalam arti yang sesungguhnya.

Proses bai'at dilakukan sebagai berikut: Guru duduk berhadap-hadapan dengan para murid yang akan dibai'at. Mereka diminta memejamkan mata, kemudian membaca kalimat tauhid Lâ ilâha illa Allâh sebanyak tiga kali, setelah itu para murid mengikutinya. ${ }^{23}$

Syarat lain, mereka yang akan bergabung dengan suatu tarekat haruslah mengetahui dengan benar nisbah atau silsilah guru dengan guru di atasnya dan seterusnya sambung menyambung satu sama lain hingga sampai kepada Rasulullah saw. Nampaknya masalah silsilah dalam tarekat 'Alawiyyah di Kabupaten HST tidak bisa disampaikan oleh gurunya, namun harus diyakini

${ }^{21}$ Mansur, Tasawuf Islam..., h. 111.

${ }^{22}$ Lihat : M. Aqîl bin 'Alî al-Mahdalî, Dirâsah fì al-Thuruq al-Shûfizyyah, diterjemahkan oleh Futuhal Arifin dengan judul Mengenal Tarekat Sufi Bagi Pemula, (Jakarta: Azan, 2002), h. 64-74.

${ }^{23}$ Asmaran As., "Aliran-aliran Tarekat...", h. 45. 
silsilahnya sampai kepada Rasulullah saw. Jika dilihat ke belakang tarekat 'Alawiyyah ini adalah gabungan dari berbagai tarekat, sehingga silsilahnya mengacu kepada tarekat yang digabungkan tersebut.

Unsur yang sangat penting dalam proses pendidikan rohani dalam sebuah tarekat adalah pemberian amalan-amalan tertentu kepada murid yang disebut dengan wirid yang di kalangan pengikut 'Alawiyyah dikenal dengan râtib. Pada tarekat 'Alawiyyah di Kabupaten HST yang dipimpin oleh H.M. Bachiet ini terdapat beberapa wirid/ratîb yang harus diamalkan oleh para jamaah.

1. Wirid Al- $\underline{\text { Haddâd }}$

Menurut sejarahnya wirid al- $\underline{\mathrm{H}} a \mathrm{ddâd}{ }^{24}$ ini tersusun setelah kedatangan

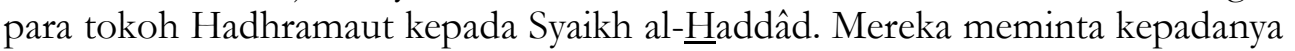
agar dapat menceagah masuknya pengaruh Syi'ah Zaidiyah ke wilayah Hadhramaut. Sehubungan dengan itu Syaikh al- $\underline{\text { H}}$ addâd mulai menyusun wirid yang kemudian dikenal dengan wirid al- $\underline{\text { Haddâd. }}$

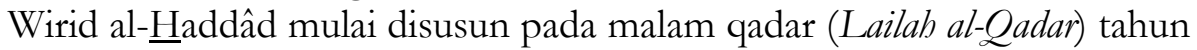
1071 H. dan mulai dibaca pada tahun 1072 H. malam Jum'at di Masjid alHaddâd di wilayah al-Hawi. Sejak saat itu wirid almasjid di Hadhramaut dan bahkan juga dibaca di sebagian masjid di Yaman, India dan Syria. Wirid al(Lâ ilâha illa Allâh) dan bacaan dengan menyebut beberapa nama Allah (alAsmâ al- $\underline{H} u s n \hat{a})$ dan doa. Cara membacanya ada yang diulang-ulang, ada yang 3 kali, 4 kali, 5 kali, 25 kali, 50 kali dan bahkan ada yang 100 kali. Bisa dikerjakan secara bersama atau sendirian. Demikianlah salah satu wirid yang dibaca oleh jamaah tarekat "Alawiyyah di Kabupaten HST. ${ }^{25}$ Bila dilakukan secara berjamaah, seorang pemimpin bacaan Râtib ini mulai memimpin dengan membaca al-Fâtihah, yang pahalanya dihadiahkan kepada Nabi saw., keluarganya, para sahabatnya, dan lain-lain. Kemudian para jamaah bersamasama membaca surah al-Fâtihah.

2. Wirid Al-Habîb Zain al-'Abidîn Ahmad Alaydrus

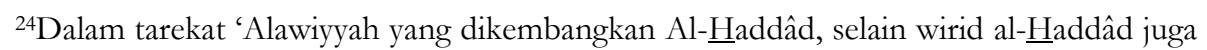
ada wirid yang lainnya, yaitu : Miftâh al-Sa'âdah wa al-Falâh fi Adそ̌kâr al-Masâ' wa al-Shabâh, berupa doa-doa yang dinisbatkan kepada para tokoh tarekat; Al-Nubdzah al-Shughrah fî Adzkâr

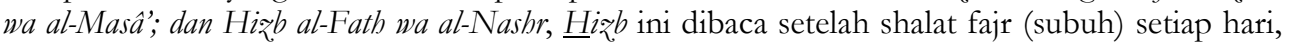
atau pada hari Jumat dan Senin, $\underline{H} i \not ̧ b$ ini dikenal juga dengan al-Wird al-Lathîf. Lihat: Ibrahim, Tharíqab 'Alawiyyah..., h. 194-195.

${ }^{25}$ Asmaran As., "Aliran-aliran Tarekat...", h. 45-46. 
Selain wirid Al-Haddâd tersebut di atas, ada wirid yang paling utama yang harus diamalkan oleh jamaah tarekat 'Alawiyyah pada majelis taklim Nûrul Muhibbîn yang ditentukan oleh guru (mursyid), yaitu wirid yang disusun oleh Habîb Zain al-'Abidîn Ahmad Alaydrus. Dikatakan susunan wirid ini telah

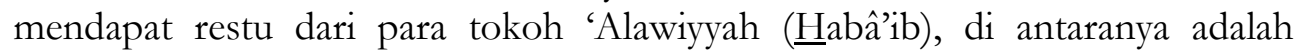

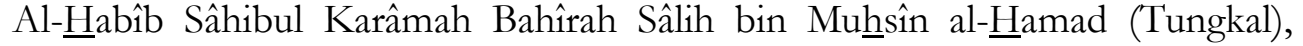

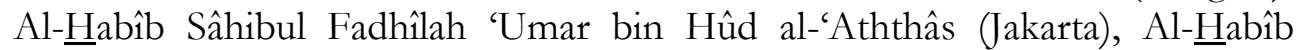

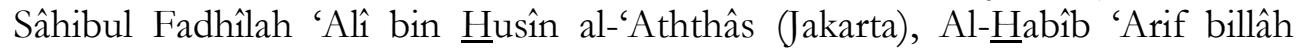
Muhammad Mastur bin Hârûn Alaydrus (Surabaya), Al- $\underline{H a b i ̂ b ~ ' A r i f ~ b i l l a ̂ h ~}$ Ahmad bin 'Alî Bafaqîh (Jakarta) dan lainnya.

Dalam membaca wirid ada beberapa adab yang harus diperhatikan oleh para jamaah, yaitu:

a. Berniat untuk mendekatkan diri kepada Allah.

b. Suci dari hadas dan najis.

c. Berpakaian putih dan menutup aurat.

d. Memakai harum-haruman.

e. Duduk dengan tenang ${ }^{26}$ dan menundukkan kepala.

f. Menghadap kiblat jika sendirian dan menghadap imam (mursyîd) apabila berjamaah.

g. Mengangkat dan membuka kedua telapak tangan ketika berdoa, kemudian menyapukannya ke wajah setelah selesai.

h. Kosong hati dan pikiran dari dunia dan selalu ingat kepada Allah.

i. Baik sangka terhadap Allah.

Khalili al-Bamar dan Hanafi dalam bukunya "Ajaran Tarekat" mengemukakan bahwa dalam melakukan doa, mambaca ratib ataupun yang amaliyah semacamnya syarat yang paling prinsip diperhatikan ialah: pertama, kebersihan jiwa. Seringkali orang berdoa, namun doanya tidak sampai pada Tuhan. Ini semata dikarenakan jiwa mereka kotor. Kedua, hendaknya dilakukan dalam keadaan bersih, suci dari najis maupun kotoran hadats. Artinya dalam melakukan doa, membaca ratib tersebut hendaknya badan dalam keadaan bersih, dan pakaian pun harus demikian juga,. Di samping itu, kita harus bisa meninggalkan segala urusan dunia, menanggalkan segala ingatan yang ada diluar doa/ratib. Pikiran harsu dikonsentrasikan pada bacaan dan doa yang ditujukan

${ }^{26} \mathrm{M}$. Amin Kurdi menjelaskan bahwa duduk di sini seperti duduk bersimpuh dalam shalat dalam posisi yang sebaliknya. Lihat: M. Amin Kurdi, Tanwîr al-Qulüb ..., h. 55. 
kepada Tuhan. Pakaian yang bersih akan mempengaruhi jiwa seseorang dalam berdoa dan membaca ratib. ${ }^{27}$

Sebelum para jamaah melaksanakan wirid tersebut terlebih dahulu membaca tawasul dan surah Yâsîn yang dipimpin langsung oleh guru. ${ }^{28}$

Demikianlah ajaran tarekat 'Alawiyyah yang berkembang di Kabupaten Hulu Sungai Tengah sebagai satu model pengembangan tarekat yang diajarkan Guru H.M. Bachiet yang tentunya punya signifikansi sosial-religius membentuk masyarakat yang berakhlak mulia dan punya resistensi yang tinggi terhadap ritualitas agama.

\section{Unsur-Unsur Neo-sufisme dalam Tarekat 'Alawiyyah}

Fazlur Rahman menyebutkan bahwa ciri utama dari neo-sufisme adalah berupa tekanan motif moral, penerapan metode zikir dan murâqabah dalam mendekati Tuhan. ${ }^{29}$ Dalam tarekat 'Alawiyyah penekanan pada pembentukan moral (akblaq al-karimah) merupakan aspek penting dalam ajaran tarekatnya. Pengikut tarekat 'Alawiyyah diarahkan pada pengintegrasian antara ibadah, akhlak dan zikir dalam perjalanan menuju Tuhan. Menurut al-Haddad tasawuf itu adalah berupa proses takballì dari segala sifat buruk seperti cinta dunia, riya, dan sombong; kemudian dibarengi dengan taballî, berupa penumbuhan sifat terpuji seperti zuhud, ikhlas, dan ta'azza li al-muslimin (turut bersedih hati kepada sesama muslim); dan tajalli, berupa pengaplikasian sifat-sifat ketuhanan dalam kehidupan, yakni dengan melakukan amal shaleh dan menjauhi perbuatan buruk, mencari nafkah dengan baik melalui jalan warâ' dan qanâ'ah.

\footnotetext{
${ }^{27}$ Khalili al-Bamar dan I Hanafi R., Ajaran Tarekat (Suatu Jalan Pendekatan Diri Terbadap Allab Swt.), (Surabaya: CV. Bintang Remaja, 1990), h. 200-204. Lihat juga: Ibnu 'Idzham, Mengatur Wirid dan Shalat Malam, (Gresik: CV. Putra Pelajar, 1999), h. 11-14. Kesucian adalah prinsip utama diterimanya shalat, demikian diungkapkan oleh Syekh 'Abd al-Qâdir al-Jîlanî. Oleh karenanya sangat tepat bahwa ketika seseorang berzikir, berdoa, membaca râtib dan amaliah lainnya kesucian z̧bâhir dan bâthin itu menjadi syarat yang prinsipil. Lihat: Syekh 'Abd al-Qâdir al-Jîlanî, Sirr al-Asrâr fî mâ Yabtaj Ilayh al-Abrâr diterjemahkan oleh Anas Syahrul Alimi dengan judul Rahasia Sufi, (Yogyakarta: Pustaka Sufi, 2003), h. 159. Di samping itu kekhusyu'an juga menjadi barometer hati seseorang itu bersih. Sangat tepat kiranya jika khusyu' ini sebagai etika dalam membaca râtib, sehingga mereka yang membacanya bisa merasakan kehadiran Muhammad dan Allah dalam setiap ibadahnya. Imam al-Ghazali, Keagungan Shalat, alih bahasa : Irwan Kurniawan, (Bandung: PT. Remaja Rosdakarya, 2000), h. 70-74.

${ }^{28}$ Asmaran As., "Aliran-aliran Tarekat...", h. 46.

${ }^{29}$ Fazlur Rahman, Gelombang Perubahan dalam Islam: Studi Fundamentalis Islam, diterjemahkan oleh Aam Fahmia dari Revival and Reform in IslamI, (Jakarta: PT. RajaGrafindo Persada, 2000), h. 150.
} 
Di samping itu, terdapat pula ajaran dari tarekat 'Alawiyyah yang memperlihatkan bahwa tarekat ini menekankan pada riyâdhah al-qulûb, yakni berupa ajaran safar (perjalanan menuju Tuhan). Safar dalam tradisi tasawuf adalah suatu cara untuk melakukan perlawanan terhadap hawa nafsu dan sebagai media pendidikan moral. Ada lima langkah yang harus ditempuh oleh seorang sâlik dalam melakukan safar, yakni: (1) menyelamatkan diri (salamah alshadr) dari segala penyakit hati; (2) berbaik sangka terhadap Allah dan terhadap makhluk-Nya; (3) Zuhud terhadap dunia dan cinta akhirat; (4) memperhatikan hak-hak makhluk Allah; (5) memuliakan ilmu, ulama, para wali, orang muslim dan mukmin.

Dalam tarekat 'Alawiyyah yang diajarkan Guru Bachiet juga sangat ditekankan ajaran zikir, baik zikir lisan maupun zikir batin. Bacaan zikir yang biasa dilafalkan adalah Lâ ilâha illa Allâh secara lisan dan kemudian diiringi dengan zikir Allâh secara lisan, dan zikir Hua dalam hati. Dalam pengucapan zikir dalam Tarekat 'Alawiyyah yang ada di Kalimantan Selatan ini tampaknya berbeda dengan zikir yang teradapat dalam Râtib al- $\underline{\text { H}}$ addâd yang lebih menekankan zikir dengan menggunakan lafal zikir nafy itsbâth, yakni dengan mengucap Lâ ilâha illa Allâh. Zikir yang seperti dikemukakan al-Haddâd ini sejalan dengan pandangan kalangan neo-sufisme, dalam hal ini menurut Ibn Taymiyah. Ibn Taymiyah menegaskan bahwa zikir dengan ism mufrâd tidaklah dianjurkan, zikir yang paling utama adalah dengan mengucap Lâ ilâha illâ Allâh, karena di situ terkandung pernyataan lengkap, yaitu peniadaan jenis penyembahan kepada sesuatu apapun, kecuali Allah satu-satunya yang boleh, berhak dan harus disembah. Zikir dengan kalimat tersebut menurut Ibn Taymiyah juga mengandung makna dan sikap tertentu yang positif dan baik., sehingga dengan zikir seseorang akan lebih aktif melakukan aktivitas yang membuatnya menjadi dekat dengan Allah swt. ${ }^{30}$

Adanya zikir yang menggunakan ism al-mufrâd dan dhamîr "Hua" tersebut sebenarnya bukan hanya terjadi dalam amalan tarekat "Alawiyyah saja, namun juga dalam tarekat-tarekat lainnya seperti tarekat Sammaniyah dan tarekat Qadiriyah Naqsyabandiyah. ${ }^{31}$ Hal tersebut dapat dipahami bahwa tarekat yang berkembang di Kalimantan Selatan, pada umumnya lebih bercorak falsafi,

\footnotetext{
${ }^{30}$ Nurcholish Madjid, Islam Agama Peradaban: Membangun Makna dan Relevansi Doktrin Islam dalam Sejarah, (Jakarta: Paramadina, 1995), h. 103.

${ }^{31}$ Alwi Shihab, Antara Tasawuf Sunni dan Tasawuf Falsafi: Akar Tasawuf di Indonesia, diterjemahkan oleh Muhammad Nursamad dari al-Tashawwuf al-Islâmî wa Atsarubu fi alTashawnuf al-Indûnîsî al-Mu'âshir, (Bandung: Pustaka Iiman, 2009), h. 214.
} 
sehingga hal tersebut juga sedikit banyaknya berpengaruh pada amalan-amalan tarekat yang sebenarnya sangat bercorak 'amali dan sunni.

Aspek penting dari neo-sufisme adalah sebuah esoterisme yang menghendaki aktif dan terlibat dalam masalah-masalah kemasyarakatan. Hal ini juga dilakukan oleh K.H. Ahmad Bachiet, sebagai guru tarekat 'Alawiyyah. Guru Bachiet adalah sosok seorang ulama yang sangat peduli kepada sesama, peduli terhadap para janda, dhu'afa, dan habaib, peduli terhadap pendidikan dan keberagamaan masyarakatnya. Kepeduliannya terhadap keadaan masyarakat di sekitarnya tersebut diapresiasikanya dalam sebuah pondok pesantren "Nurul Muhibbin" yang berfungsi sebagai lembaga pendidikan keagamaan dan sebagai majelis taklim tarekat "Alawiyyah. Sebagaimana dikemukakan oleh Fazlur Rahman bahwa para pemimpin tarekat telah memberikan suatu perubahan yang segar dalam hal perasaan keagamaan (sense of religious) yang lebih sesuai dengan pembangunan masyarakat yang baik dan bermoral. Dari sini muncullah suatu orientasi yang lebih positif kepada dunia, moral, masalah-masalah sosial dan ekonomi daripada persoalan eskatologis, seperti: kematian, surga dan neraka. Dari persepsi ini nantinya diharapkan mempunyai pengaruh yang positif terhadap dunia pendidikan dan kehidupan sekarang, sehingga menghasilkan masyarakat muslim yang berperadaban modern dan religius. ${ }^{32}$

\section{Penutup}

Kalimantan Selatan merupakan daerah yang juga banyak berkembang berbagai aliran tarekat. Salah satunya adalah tarekat 'Alawiyyah yang cukup berkembang subur, terutama di daerah Kabupaten Hulu Sungai Tengah yang diajarkan oleh Guru Bachiet, seorang ulama yang cukup berpengaruh dan kharismatik di daerahnya.

Terlihat dari ajaran tarekat yang diajarkan oleh Guru Bachiet masih mempertahankan ajaran tarekat 'Alawiyyah yang dikembangkan Al- $\underline{H} a d d a ̂ d$, seorang ulama sufi Hadhrami yang berpengaruh pada abad ke-17, terutama masih diwajibkannya murid (jamaah) tarekat 'Alawiyyah di sini membaca wirid al-프addâd.

Adapun tentang kemuktabarahan tarekat 'Alawiyyah ini dapat dilihat dari ajarannya yang sangat mementingkan latihan rohani (riyâdhah al-qulüb) dan amalan-amalan guna mendekatkan diri kepada Allah. Tarekat 'Alawiyyah di

${ }^{32}$ Fazlur Rahman, Islam, (Chicago and London: University of Chicago Press, 1979), 
Kalimantan Selatan yang diajarkan oleh Guru Bachieit ini juga menekankan pada aspek moral pada para muridnya, pembentukan moral yang dilakukannya melalui pengajian majelis taklim dan contoh nyata dalam menyantuni para janda, dhuafa dan habaib. Pembentukan moral dan aktivitas sosial tersebut merupakan unsur terpenting dalam neo-sufisme. Di samping itu zikir dan muraqabah yang dilakukan juga merupakan unsur neo-sufisme. Akan tetapi penggunaan zikir ism al-mufrad dan dhamir "Hua" merupakan pengaruh tasawuf falsafi yang banyak ditemui di Kalimantan Selatan. Pengamalan tarekat dengan tanpa mengesampingkan aktivitas sosial kemasyarakatan adalah bagian dari neo-sufisme yang perlu dikembangkan, sehingga para pengamal tasawuf (tarekat) juga terlibat langsung dengan persoalan yang dihadapi masyarakat saat ini. Dengan demikian dalam tarekat terdapat keseimbangan (tawazun) antara aspek ukhrawi dan duniawi.

\section{Daftar Pustaka}


Asmaran As., "Aliran-aliran Tarekat di Kalimantan Selatan ('Alawiyyah, Sammaniyyah dan Tijaniyyah)"dalam Kandil, Edisi 4, tahun II, Pebruari 2004.

Azra, Azyumardi, "Pengantar", dalam Umar Ibrahim, Tharîah 'Alawiyyah: Napak Tilas dan Studi Kritis atas Sosok dan Pemikiran Allamah Sayyid 'Abdullâh al-Haddâd Tokoh Sufi Abad ke-17, Bandung, Mizan, 2001.

al-Bamar, Khalili, dan I Hanafi R., Ajaran Tarekat (Suatu Jalan Pendekatan Diri Terbadap Allab Swt.), Surabaya, CV. Bintang Remaja, 1990.

Bruinessen, Martin van, "Pengantar" dalam Mahmud Sujuthi, Politik Tarekat Qadiriyah wa Naqsyabandiyah Jombang, Yogyakarta : Galang Press, 2001.

-------, Tarekat Naqsyabandiyah di Indonesia, Bandung, Mizan, 1995.

al-Ghazâli, Keagungan Shalat, alih bahasa : Irwan Kurniawan, Bandung, PT. Remaja Rosdakarya, 2000.

Hawwa, Sa'id, Al-Mustakblash fì tazkiyah al-Anfus, diterjemahkan oleh Aunur Rafiq Shaleh Tamhid dengan judul Mensucikan Jiwa / Konsep Taækiyatunnafs Terpadu: Intisari Ibya' 'Ulümuddìn al-Ghazâl, Jakarta, Robbani Press, 2000.

Ibnu 'Idzham, Mengatur Wirid dan Shalat Malam, Gresik, CV. Putra Pelajar, 1999.

Ibrahim, Umar, Tharíqah 'Alawiyyah: Napak Tilas dan Studi Kritis atas Sosok dan Pemikiran Allamah Sayyid 'Abdullâh Al-Haddâd Tokob Sufi Abad ke-17, Bandung : Mizan, 2001.

-------, Tarekat Alawiyyah Bukan Organisasi Tarekat, dalam Sufi Menuju Jalan Ilahi, Edisi 16, September 2001.

al-Jîlanî, 'Abd al-Qâdir, Sirr al-Asrâr fî̀ mâ Yabtaj Ilayh al-Abrâr diterjemahkan oleh Anas Syahrul Alimi dengan judul Rahasia Sufi, Yogyakarta, Pustaka Sufi, 2003.

al-Kurdi, Muhammad Amin, Tanwîr al-Qulûb, Bab III, diterjemahkan oleh Ilyas Siraj dengan judul Berjalan Menuju Tuban: Kode Etik Tarekat Naqsyabandiyah, Yogyakarta, Harapan Utama, 2001.

Madjid, Nurcholish, Islam Agama Peradaban: Membangun Makna dan Relevansi Doktrin Islam dalam Sejarah, Jakarta, Paramadina, 1995. 
Mansur, M. Laily, Ajaran dan Teladan Para Sufi, Jakarta, Raja Grafindo Persada, 1999.

-------, Tasawuf Islam : Mengenal Aliran dan Ajaran, Banjarmasin, Lambung Mangkurat University Press, 1992.

al-Mahdalî, 'Alî, Dirâsah fì al-Thuruq al-Shûfiyyah, diterjemahkan oleh Futuhal Arifin dengan judul Mengenal Tarekat Sufi Bagi Pemula, Jakarta, Azan, 2002.

Rahman, Fazlur, Islam, Chicago and London, University of Chicago Press, 1979.

Shihab, Alwi, Antara Tasawnf Sunni dan Tasawnf Falsafi: Akar Tasawnf di Indonesia, diterjemahkan oleh Muhammad Nursamad dari al-Tashawwnu al-Islâmî wa Atsarubu fi al-Tashawwnf al-Indûnîsî al-Mu'âshir, Bandung, Pustaka Iiman, 2009.

Syaikhu, Nanang, Tarekat Alawiyyah, dalam Sufi Menuju Jalan Ilahi, Edisi 16, September 2001

Valiuddin, Mir, Contemplative Disciplines in Sufism, diterjemahkan oleh M.S. Nasrlloh dengan judul Zikir dan Kontemplasi dalam Tasawuf, Bandung, Pustaka Hidayah, 1997. 